\title{
TINJAUAN AKUNTANSI TERHADAP FITUR-FITUR PRIORITAS GENERASI MILENIAL DALAM MEMILIH BANK
}

\author{
Fongnawati Budhijono \\ Universitas Prasetiya Mulya \\ fongnawati@gmail.com \\ Olivia V. B. Nainggolan \\ Sekolah Tinggi Ilmu Ekonomi Wiyatamandala \\ oliviavnainggolan@gmail.com
}

\begin{abstract}
This study aims to explore the features of the millennial generation's concern in choosing banks from an accounting review. Data obtained through a survey of 118 respondents belonging to millennial generation in several cities in Indonesia who are customers of certain banks using Google forms and questionnaires with closed choices. Sampling was done by purposive sampling technique. Data analysis was performed with central tendency and Contingency Table Analysis. It was found that the Bank's Reputation, Availability of ATM Machines, and Reliable M-Banking Facilities were 3 bank features that were a priority for millennial generation in bank selection. The research findings do not indicate that millennial customers directly empower accounting information in determining bank selection based on the features they choose. It was found that there was a relationship between gender with factors that were the 3 highest priorities of respondents in deciding to choose a particular bank. There is no relationship between the area of origin with factors that are the 3 highest priorities of respondents in deciding to choose a particular bank.
\end{abstract}

Keywords: Millennial, Features, Accounting, Gender, Area of Origin, Bank

\section{PENDAHULUAN}

Industri perbankan merupakan salah satu motor penggerak perekonomian suatu negara. Tidak dapat dipungkiri bahwa Indonesia masih membutuhkan perbankan sebagai salah satu fasilitator terbesarnya dalam menyalurkan dana. Disokong dengan data yang disediakan oleh Otoritas Jasa Keuangan pada Statistik Perbankan Indonesia edisi Januari 2019, penyaluran kredit perbankan Indonesia bertumbuh ratarata sebesar 7,09 \% untuk Bank Umum dan $8,57 \%$ untuk Bank Perkreditan Rakyat dengan pencatatan terakhir menunjukkan kredit disalurkan sebesar 
7.667.803 miliar dan 130,523 miliar (Otoritas Jasa Keuangan, 2019). Seiring berkembangnya zaman, bank juga telah mengikuti perkembangan global sepertihalnya menggunakan teknologi sebagai perangkat utama untuk meningkatkan kinerja perusahaan serta menarik minat nasabah. Hampir semua bank sudah menggunakan teknologi tersebut sebagai daya tarik bagi nasabah-nasabah yang ada di Indonesia. Dengan banyaknya pilihan perbankan yang menyediakan berbagai fitur menarik tentunya masyarakat dapat memilih bank yang sesuai dengan kepentingannya mulai dari bank yang lebih memiliki jaminan keamanan hingga kemudahan penggunaan ataupun layanan yang paling baik. Dalam era globalisasi seperti saat ini, media informasi dan teknologi terus berkembang cepat setiap harinya. Nilai praktis yang ditawarkan oleh perkembangan teknologi tersebut telah berdampak pada berubahnya kebiasaan dan budaya yang ada di dalam masyarakat (Hinson and Okoe, 2013). Sehingga sekarang ini, masyarakat cenderung mengalami ketergantungan terhadap hal-hal yang bersifat cepat dan praktis. Saat ini budaya yang berkembang di masyarakat telah menciptakan sebuah pandangan baru di masyarakat, tidak hanya dalam kehidupan sehari-hari, melainkan juga dalam preferensi pemilihan bank. Kepercayaan masyarakat terhadap pembayaran digital juga terus berkembang setiap harinya. Hal ini telah mengakibatkan semakin banyak faktor yang dapat mempengaruhi seseorang dalam memilih bank, pada mulanya mungkin pertimbangan utama dalam memilih bank adalah perihal keamanan yang setidaknya dapat ditelusur dari informasi yang digali dari laporan keuangan bank yang disusun menurut kaidah akuntansi yang berlaku. Tapi sekarang ini, seiring dengan berkembanganya era digitalisasi ekonomi, layanan-layanan yang diberikan bank seperti mobile banking dan jumlah mesin ATM juga semakin menjadi dipertimbangkan oleh masyarakat (Saleh et al, 2013), yang disinyalir justru lebih memperoleh perhatian nasabah bank daripada pengungkapan kualitas kinerja bank yang setidaknya dapat diungkap dari laporan keuangan bank maupun keunggulan aspek corporate governance nya (Lo, A. W., Wong, R. M., \& Firth, M, 2010). Berdasarkan data dari Otoritas Jasa Keuangan (OJK), 
terhitung sejak bulan November 2018, di Indonesia terdapat 115 bank umum yang beroperasi di Indonesia (Otoritas Jasa Keuangan, 2019). Bank-bank tersebut memiliki fokus yang berbedabeda, ada bank yang memfokuskan operasionalnya pada layanan di sisi kredit, deposito dan layanan-layanan lainnya (Otoritas Jasa Keuangan. (2019a).. Dengan layanan dan fasilitas yang disediakan, bank-bank tersebut memiliki kelebihan dan kekurangannya masing-masing. Dengan semakin beragamnya layanan yang diberikan perbankan dan semakin beragamnya preferensi masyarakat dalam pemilihan bank, menarik untuk meneliti fitur-fitur apa yang dianggap penting oleh nasabah bank. Masing-masing nasabah pastinya memiliki alasan tersendiri untuk menabung di bank tertentu dan tidak sedikit dari mereka yang punya tingkatan prioritas dalam memilih bank sebagai tempat mereka mempercayakan uang mereka. Generasi milenial atau generasi $\mathrm{Y}$ atau yang biasa juga disebut dengan generation me atau echo boomers, saat ini menjadi daya tarik dan mempengaruhi hampir di semua industri Generasi milenial yang memiliki keterlibatan lebih terhadap teknologi dan dianggap lebih 'melek' teknologi (Twenge, 2010; Utomo, 2019) disinyalir memiliki pertimbangan yang 'khusus' terhadap fitur-fitur yang ditawarkan oleh bank pada waktu mereka memutuskan untuk memilih bank (Chigamba, 2011). Penelitian ini bertujuan untuk mengeksplorasi fiturfitur yang menjadi perhatian generasi milenial dalam memilih bank dari tinjauan akuntansi dan untuk mengetahui apakah jenis kelamin dan asal daerah memiliki keterkaitan terhadap fitur-fitur prioritas pemilihan bank (Alvara Research Center, 2017). Jenis kelamin merupakan variabel yang menarik perhatian dengan pertimbangan nasabah perempuan disinyalir lebih kuat dalam aspek emosi sedangkan nasabah laki-laki lebih pragmatis dan rasional (Lara, J. M. G., et al, 2017).). Asal daerah juga merupakan variabel yang menarik dengan pertimbangan asal daerah memiliki pengaruh terkait dengan kearifan lokal yang disinyalir membentuk pola pikir dan kebiasaan dari nasabah bank serta ketidakmerataan adopsi kehidupan digital telekomunikasi (APJII, 2018) yang sangat dimungkinkan dapat mempengaruhi 
prioritasnya dalam memilih fitur-fitur

\section{TELAAH LITERATUR}

Dikutip dari kominfo.go.id (Situs Kominfo, 2016), kaum Milenial adalah generasi muda yang terlahir antara tahun 1980-an sampai 2000, sedangkan Deloitte (2018) menyatakan bahwa milenial adalah orang yang lahir antara Januari 1983 dan Desember 1994. Milenial dikenal sebagai individu yang proaktif dan ahli teknologi serta lebih cenderung menghargai waktu luang (Twenge, 2010). Karakteristik lain dari generasi ini adalah pentingnya keseimbangan kehidupan dan kerja (Ozcelik, 2015). Pengaturan kerja yang fleksibel adalah aspek lain dari milenial. Strauss dan Neil Howe (2000) menjelaskan, ada tujuh karakter Millenial yaitu: spesial, terlindungi, percaya diri, berwawasan kelompok, konvensional, tahan tekanan dan mengejar pencapaian. Menurut Sebastian (2016) dan Badan Pusat Statistik (2018), ada beberapa karakteristik dari generasi milenial, yaitu ingin serba cepat, mudah berpindah pekerjaan dalam waktu singkat, kreatif, dinamis, melek teknologi, dekat dengan media sosial, bank.

dan sebagainya. Data BPS tahun 2018 (Badan Pusat Statistik, 2018) mencatat, bahwa populasi generasi millenial adalah sekitar 90 juta orang.atau 33,75 persen dari total penduduk Indonesia. Dan hal ini tentunya dimanfaatkan oleh semua industri terutama perbankan yang banyak melakukan inovasi terutama dalam layanan mobile banking. Saleh et al (2013) dalam penelitiannya di Malaysia mengungkapkan bahwa faktor yang paling signifikan mempengaruhi customer dalam memilih bank adalah aksesibilitas dimana terbagi atas beberapa item yaitu fasilitas ATM, lokasi ATM yang nyaman, ketersediaan layanan ATM 24 jam, bank memiliki layanan cepat dan bank memiliki fasilitas internet banking. Temuan Fathelrahman (2019), menyatakan bahwa keputusan pemilihan bank di Sudan tergantung pada efisiensi korporat bank dalam hal kepercayaan dan komitmen, privasi dan kerahasiaan, efisiensi dalam melaksanakan transaksi, efisiensi layanan frontliner dan sikap ramah dan responsif pegawai perbankan itu sendiri. Hinson dan Okoe (2013) 
menemukan bahwa faktor penentu pemilihan Bank oleh mahasiswa di Universitas Ghana adalah kenyamanan dan hemat waktu dalam mengakses layanan perbankan. Penelitian ini juga sejalan dengan penelitian Chigamba (2011) dimana mahasiswa di Afrika Selatan tidak ingin menghabiskan waktu dalam antrian dan lebih mengutamakan teknologi seperti ATM, e-Banking, dan Phone banking, Hasil riset dari Utomo (2019) menunjukan bahwa 94,4\% milenial Indonesia telah terkoneksi dengan internet. Seperti yang dikutip dari idntimes dimana perilaku millennial yang cukup menarik perhatian adalah pola hidup cashless. Tidak heran apabila perbankan online menjadi sangat diminati mengingat milenial tumbuh dengan banyaknya akses informasi seperti media sosial dan

\section{METODE PENELITIAN}

Data yang digunakan dalam penelitian ini diperoleh melalui survey terhadap generasi milenial yang tersebar di beberapa kota di Indonesia. Pengambilan sampel dilakukan dengan teknik purposive sampling. Sebagai responden adalah mereka yang teknologi digital. Nasabah yang cermat dalam memilih bank seyogyanya mempertimbangkan bank pilihannya atas dasar fitur-fitur yang dirasa mampu mengamankan dananya disamping fiturfitur yang memberikan kemudahan dalam bertransaksi. Dalam hal ini laporan keuangan perusahaan yang disusun atas dasar kaidah-kaidah akuntansi yang berlaku dapat digunakan oleh kandidat nasabah maupun pihakpihak yang berkepentingan untuk memprediksi kinerja bank-bank dan keunggulan pengelolaannya (Yunietha, \& Palupi, A., 2017; Mathova, A., Perdana, H. D., \& Rahmawati, I. $\mathrm{P}$,2017) sebelum memutuskan untuk mempercayakan dananya di bank tersebut (Barth, M. E., Landsman, W. R., \& Lang, M. H. (2008).

tergolong dalam generasi milenial yang merupakan nasabah dari bank-bank tertentu. Kepada responden ditanyakan mengenai fitur-fitur yang menjadi bahan pertimbangkan mereka saat memilih bank untuk menabung. Survey dilakukan kepada 118 responden yang termasuk generasi mienial dengan 
menggunakan google form dan kuesioner dengan pilihan tertutup. Analisis data dilakukan dengan nilai rata-rata dan Contingency Table Analysis. Nasabah yang peduli terhadap penggunaan kualitas informasi yang disusun berdasar kaidah-kaidah akuntansi yang berlaku diharapkan akan memberi perhatian utama terhadap pokok-pokok berikut:

6). Kemampuan pengelola bank dalam mengelola bank

7). Kinerja Good Corporate Governance dari Bank

17). Sejauh ini keuntungan yang diraih bank selalu positif

25). Pelayanan petugas bank yang ramah, tepat waktu, cepat dan sigap.

26). Ketersediaan perangkat CCTV (kamera pengawas) pada setiap counter ATM maupun di dalam bank.

Nasabah yang peduli terhadap risiko diharapkan akan memberi perhatian utama terhadap pokok-pokok berikut:

1). Reputasi Bank

2). Besarnya bunga tabungan yang diberikan

3). Bank termasuk yang dijamin Lembaga Penjamin Simpanan (LPS) 19). Bank milik pemerintah
Contingency Table digunakan untuk mengklasifikasikan pengamatan berdasarkan dua karakteristik yang dapat diklasifikasikan. Contingency Table juga merupakan sebuah tabulasi silang yang secara bersamaan merangkum dua variabel yang menjadi perhatian. Dalam rangka melakukan analisis tabel kontingensi digunakan salah jenis tipe 1 atau alpha 0,05 . Uji dengan analisis tabel kontingensi dilakukan terhadap hubungan jenis kelamin dengan fitur-fitur prioritas pemilihan bank dan hubungan asal daerah dengan fitur-fitur prioritas pemilihan bank.

1.Untuk mengetahui apakah jenis kelamin responden berpengaruh terhadap fitur-fitur prioritas pemilihan bank, dirumuskan hipotesis sebagai berikut:

$\mathrm{H}_{\mathrm{o}}$ : Tidak terdapat hubungan antara jenis kelamin dengan faktor yang menjadi 3 prioritas tertinggi responden dalam memutuskan untuk memilih bank.

$\mathrm{H}_{1}$ : Terdapat hubungan antara jenis kelamin dengan fitur yang menjadi 3 prioritas tertinggi responden dalam memutuskan untuk memilih bank. 
2. Untuk mengetahui apakah asal tertinggi responden dalam daerah responden berpengaruh memutuskan untuk memilih bank. terhadap fitur-fitur prioritas $\mathrm{H}_{1}$ : Terdapat hubungan antara asal pemilihan bank, dirumuskan hipotesis sebagai berikut:

$\mathrm{H}_{\mathrm{o}}$ : Tidak terdapat hubungan antara asal daerah dengan 3 prioritas daerah dengan 3 prioritas tertinggi responden dalam memutuskan untuk memilih bank.

\section{HASIL DAN PEMBAHASAN}

Dari jawaban responden terhadap Questionnaire yang disebarkan, dapat dirangkum rata-rata tingkat kepentingan para responden yang adalah generasi

milenial terhadap fitur-fitur yang berhubungan dengan alasan mereka memilih bank sebagaimana tertera pada Tabel 4.1 berikut:

Tabel 4.1.

Rata-rata tingkat kepentingan responden terhadap fitur-fitur yang berhubungan dengan alasan memilih bank

\begin{tabular}{|c|c|c|}
\hline No & Faktor & $\begin{array}{c}\text { Rata-rata } \\
\text { Tingkat kepentingan }\end{array}$ \\
\hline 1 & Reputasi Bank & 4.6949 \\
\hline 2 & $\begin{array}{c}\text { Besarnya bunga tabungan yang } \\
\text { diberikan }\end{array}$ & 3.9915 \\
\hline 3 & $\begin{array}{l}\text { Bank termasuk yang dijamin Lembaga } \\
\text { Penjamin Simpanan (LPS) }\end{array}$ & 4.4237 \\
\hline 4 & Kedekatan Bank dengan tempat tinggal & 3.7373 \\
\hline 5 & $\begin{array}{c}\text { Kemudahan dalam membuka rekening } \\
\text { tabungan }\end{array}$ & 4.2797 \\
\hline 6 & $\begin{array}{l}\text { Kemampuan pengelola bank dalam } \\
\text { mengelola bank }\end{array}$ & 4.3305 \\
\hline
\end{tabular}


Tabel 4.2

Rata-rata tingkat kepentingan responden terhadap fitur-fitur yang berhubungan dengan alasan memilih bank

\begin{tabular}{|c|c|c|}
\hline No & Faktor & $\begin{array}{c}\text { Rata-rata } \\
\text { Tingkat kepentingan }\end{array}$ \\
\hline 7 & Kinerja Good Corporate Governance dari Bank & 4.2966 \\
\hline 8 & Keberadaan kenalan di bank tersebut & 2.6695 \\
\hline 9 & Keberadaan kerabat/saudara di bank tersebut & 2.7288 \\
\hline 10 & Fasilitas internet bankingnya lengkap & 4.2881 \\
\hline 11 & Fasilitas mobile banking handal & 4.4661 \\
\hline 12 & Merk Bank terkenal & 4.2797 \\
\hline 13 & $\begin{array}{c}\text { Fasilitas tabungan banyak menawarkan } \\
\text { program diskon }\end{array}$ & 3.9831 \\
\hline 14 & Jenis Produk yang ditawarkan & 3.7712 \\
\hline 15 & Bank yang sudah langganan dipakai keluarga & 4.0847 \\
\hline 16 & Biaya administrasi buku tabungan & 3.7203 \\
\hline 17 & $\begin{array}{c}\text { Sejauh ini keuntungan yang diraih bank selalu } \\
\text { positif }\end{array}$ & 3.9576 \\
\hline 18 & Rekomendasi dari teman/saudara & 3.2457 \\
\hline 19 & Bank milik pemerintah & 2.8983 \\
\hline 20 & Bank milik swasta & 3.3644 \\
\hline 21 & $\begin{array}{l}\text { Kemudahan dalam bertransaksi menggunakan } \\
\text { fitur-fitur yang disediakan Bank }\end{array}$ & 4.2457 \\
\hline 22 & $\begin{array}{l}\text { Kecepatan dalam bertransaksi sehubungan } \\
\text { fitur-fitur yang disediakan bank }\end{array}$ & 4.2966 \\
\hline 23 & $\begin{array}{l}\text { Mesin ATM tersedia melimpah dan tersedia } \\
\text { dimana-mana }\end{array}$ & 4.4746 \\
\hline 24 & $\begin{array}{c}\text { Fleksibilitas kartu ATM pada mesin ATM } \\
\text { milik bank lain (ATM bersama) }\end{array}$ & 4.4237 \\
\hline 25 & $\begin{array}{c}\text { Pelayanan petugas bank yang ramah, tepat } \\
\text { waktu, cepat dan sigap. }\end{array}$ & 4.1356 \\
\hline 26 & $\begin{array}{c}\text { Ketersediaan perangkat CCTV (kamera } \\
\text { pengawas) pada setiap counter ATM maupun } \\
\text { di dalam bank }\end{array}$ & 4.2033 \\
\hline 27 & Jam Operasional Bank & 3.9068 \\
\hline 28 & Bank Syariah & 2.2797 \\
\hline 29 & Tidak ada biaya administrasi bulanan & 3.7712 \\
\hline 30 & $\begin{array}{c}\text { Bank menawarkan hadiah saat pembukaan } \\
\text { rekening }\end{array}$ & 3.3559 \\
\hline
\end{tabular}


Melalui rangkuman faktor kepentingan dari 118 responden, didapati bahwa Reputasi Bank (dengan nilai rata-rata 4,6949), Ketersediaan Mesin ATM (dengan nilai rata-rata 4,4746), serta Fasilitas M-Banking Handal (dengan nilai rata-rata 4,4661) merupakan 3 fitur bank yang menjadi prioritas bagi generasi milenial dalam pemilihan bank. Temuan ini senada dengan Saleh et al (2013), meskipun tidak semua fiturnya sama. Temuan penelitian tidak menunjukkan bahwa nasabah milenial secara langsung memberdayakan informasi akuntansi dalam menentukan pemilihan bank atas dasar fitur-fitur yang dipilihnya. Reputasi bank yang diasumsikan berkorelasi positif dengan kinerja bank dapat diasumsikan bahwa nasabah milenial tidak secara langsung memberdayakan informasi akuntansi dalam menentukan pemilihan bank. Dalam hal ini asumsi tersebut memerlukan pengujian atas dasar data empiris. Komposisi responden pemilih ke tiga fitur tersebut tertera pada Tabel 4.2 .

Tabel 4.3 Komposisi responden pemilih

\begin{tabular}{|c|c|c|c|}
\hline No & Fitur bank prioritas & Frekuensi & $\begin{array}{l}\text { Frekuensi } \\
\text { relatif } \\
(\%)\end{array}$ \\
\hline 1 & Reputasi Bank & 57 & 48,31 \\
\hline 2 & $\begin{array}{l}\text { Mesin ATM tersedia melimpah } \\
\text { dan tersedia dimana-mana }\end{array}$ & 23 & 19,49 \\
\hline 3 & $\begin{array}{c}\text { Fasilitas Mobile Banking yang } \\
\text { handal }\end{array}$ & 15 & 12,71 \\
\hline \multirow[t]{2}{*}{4} & Lain-lain & 23 & 19,49 \\
\hline & TOTAL & 118 & 100 \\
\hline
\end{tabular}

Dari penelusuran lebih lanjut terkait jenis kelamin responden didapati bahwa preferensi tingkat kepentingan menunjukkan adanya perbedaan sebagaimana tertera pada Tabel 4.3. Responden perempuan 
cenderung mementingkan fitur reputasi bank, ketersediaan mesin ATM, fasilitas m-banking. Sedangkan, responden laki-laki cenderung mementingkan reputasi bank, bank yang dijamin LPS, dan Merk Bank terkenal dalam pemilihan Bank. Kecenderungan yang teridentifikasi menyatakan bahwa responden perempuan lebih menekankan pada fitur-fitur yang menunjang kenyamanan mereka dalam bertransaksi sehubungan aktivitas keseharian. Ketersediaan mesin ATM yang melimpah menjadikan responden mudah untuk menarik uang setiap saat membutuhkan, menyetor maupun melakukan transfer serta transaksi keuangan lainnya melalui mesin ATM. Ketersediaan fasilitas mobile banking juga menyediakan aspek kenyamanan bagi responden yang memungkinkan mereka melakukan banyak alternatif transaksi keuangan darimana saja dan kapan saja sehingga menghemat biaya, waktu dan tenaga serta lebih menjamin aspek keamanan fisik dari penggunanya. Dengan adanya mobile banking, kehidupan nasabah dipermudah tiap harinya. Nasabah tidak perlu datang ke ATM terdekat untuk melakukan transaksi dengan orang lain. Dengan mengklik sebuah aplikasi, nasabah sudah bisa melakukan transaksi dengan orang lain. Responden dengan jenis kelamin laki-laki nampaknya lebih memberi penekanan dan lebih peduli terhadap risiko sehingga aspek penjaminan bank oleh LPS menjadi perhatian mereka. Dengan dijamin oleh LPS secara psikologis responden akan merasa lebih tenang dan nyaman mempercayakan dananya disimpan di bank. Aspek reputasi bank dan merek bank yang terkenal diasumsikan juga merupakan aspek yang menjadi penjamin bahwa bank-bank yang memiliki reputasi bagus dan dengan merek terkenal semestinya adalah bank-bank yang dikelola dengan baik sehingga menjadi jaminan keamanan dana yang dikelola oleh bank tersebut. Meski didapati perbedaan fitur prioritas terkait jenis kelamin laki-laki dan perempuan, namun secara keseluruhan, reputasi bank menjadi prioritas utama bagi responden laki-laki maupun perempuan dalam memilih Bank. 
Tabel 4.4 Fitur prioritas terkait jenis kelamin

\begin{tabular}{cccc} 
Jenis & \multicolumn{3}{c}{ Prioritas } \\
Kelamin & $\mathbf{1}$ & $\mathbf{2}$ & $\mathbf{3}$ \\
Perempuan & $\begin{array}{c}\text { Reputasi } \\
\text { Bank }\end{array}$ & $\begin{array}{c}\text { Ketersediaan } \\
\text { Mesin ATM }\end{array}$ & $\begin{array}{c}\text { Fasilitas M- } \\
\text { Banking } \\
\text { Handal }\end{array}$ \\
Laki-Laki & $\begin{array}{c}\text { Reputasi } \\
\text { Bank }\end{array}$ & Bank & $\begin{array}{c}\text { Merk Bank } \\
\text { Terkenal }\end{array}$ \\
& & & \\
\hline
\end{tabular}

Konfirmasi terhadap adanya hubungan variabel jenis kelamin dengan pemilihan fitur prioritas dilakukan dengan analisis Contingency Table sebagaimana tampak pada Tabel 4.4. Pengujian dilakukan terhadap fitur
Reputasi Bank, Ketersediaan Mesin ATM, serta Fasilitas M-Banking Handal yang merupakan 3 fitur bank yang menjadi prioritas bagi generasi milenial dalam pemilihan bank

Tabel 4.5 Contingency Table Variabel jenis kelamin dengan pemilihan fitur prioritas

\begin{tabular}{|c|c|c|c|c|}
\hline \multirow[b]{2}{*}{ Jenis kelamin } & \multicolumn{3}{|c|}{ Prioritas } & \\
\hline & $\begin{array}{c}1 \\
\text { Reputasi Bank }\end{array}$ & $\begin{array}{c}2 \\
\text { Ketersediaan } \\
\text { Mesin ATM }\end{array}$ & $\begin{array}{c}3 \\
\text { Mobile Banking }\end{array}$ & Total \\
\hline Laki-laki & 24 & 7 & 14 & 45 \\
\hline Perempuan & 33 & 26 & 14 & 73 \\
\hline Total & 57 & 33 & 28 & 118 \\
\hline
\end{tabular}

Dari analisis tabel kontingensi diperoleh Chi-square statistic sebesar 6,0574 > critical value $(5,991)$. Hasil pengujian adalah menolak hipotesis nol. Dengan demikian data empiris memberikan dukungan terhadap adanya hubungan 
antara jenis kelamin dengan faktorfaktor yang menjadi 3 prioritas tertinggi responden dalam memutuskan untuk menabung di Bank tertentu. Konfirmasi terhadap adanya hubungan variabel asal daerah responden dengan pemilihan fitur prioritas dilakukan dengan analisis Contingency Table sebagaimana tampak pada Tabel 4.5. Pengujian dilakukan terhadap fitur Reputasi Bank, Ketersediaan Mesin ATM, serta Fasilitas M-Banking Handal yang merupakan 3 fitur bank yang menjadi prioritas bagi generasi milenial dalam pemilihan bank

Tabel 4.6 Contingency Table Variabel Asal daerah dengan pemilihan fitur prioritas

\begin{tabular}{|c|c|c|c|c|}
\hline \multicolumn{5}{|c|}{ Prioritas } \\
\hline $\begin{array}{c}\text { Asal } \\
\text { Daerah }\end{array}$ & $\begin{array}{c}1 \\
\text { Reputasi } \\
\text { Bank }\end{array}$ & $\begin{array}{c}2 \\
\text { Ketersediaan } \\
\text { Mesin ATM }\end{array}$ & $\begin{array}{c}3 \\
\text { Mobile } \\
\text { Banking }\end{array}$ & Total \\
\hline $\begin{array}{c}\text { Jakarta } \\
\text { Luar }\end{array}$ & 36 & 20 & 16 & 72 \\
\hline Jakarta & 21 & 13 & 12 & 46 \\
\hline Total & 57 & 33 & 28 & 118 \\
\hline
\end{tabular}

Porsi responden yang berasal dari Jakarta adalah $61 \%$. Porsi responden yang berasal dari luar Jakarta adalah $39 \%$ (yang terdiri dari responden dengan asal daerah Bekasi, Bogor, Surabaya, Lampung, Semarang, Pontianak, Tangerang, Jambi dan Palembang). Hasil pengujian mendapati nilai statistik chi square $(0,28886)<$ nilai kritis $(5,991)$ dengan demikian dinyatakan tidak cukup bukti untuk menolak $\mathrm{H}_{0}$. Dengan hasil ini dapat diartikan tidak terdapat hubungan antara asal daerah dengan faktor-faktor yang menjadi 3 prioritas tertinggi responden dalam memutuskan untuk menabung di Bank tertentu. Temuan ini tidak mendukung sinyalemen kehidupan digital telekomunikasi belum teradopsi secara merata (APJII, 2018) karena penggunaan internet yang tidak proporsional pada banyak daerahdaerah di tanah air nampaknya tidak menghalangi niat generasi milenial mendasarkan pilihan bank atas fiturfitur yang bernuansa teknologi. 


\section{SIMPULAN \& SARAN}

\subsection{Simpulan}

1. Didapati bahwa Reputasi Bank, Ketersediaan Mesin ATM, serta Fasilitas M-Banking Handal merupakan 3 fitur bank yang menjadi prioritas bagi generasi milenial dalam pemilihan bank. Temuan penelitian tidak menunjukkan bahwa nasabah milenial secara langsung memberdayakan informasi akuntansi dalam menentukan pemilihan bank atas dasar fitur-fitur yang dipilihnya.

2. Didapati adanya hubungan antara jenis kelamin dengan faktor-faktor yang menjadi 3 prioritas tertinggi responden dalam memutuskan untuk menabung di Bank tertentu.

3. Tidak terdapat hubungan antara asal daerah dengan faktor-faktor yang menjadi 3 prioritas tertinggi responden dalam memutuskan untuk menabung di Bank tertentu.

\subsection{Saran}

1) Seiring dengan berkembangnya era globalisasi seperti saat ini dan dengan adanya inovasi serta teknologi baru yang terus berkembang, pihak perbankan sebaiknya lebih memperhatikan segala perkembangan yang terus terjadi agar lebih dapat mengikuti kebutuhan dan keinginan dari pihak konsumen. Sebab seiring berjalannya waktu masyarakat cenderung mengarah pada segala hal yang mudah diakses yang mengarah kepada peningkatan efektivitas dan efisiensi.

2) Sehubungan dengan reputasi bank yang diasumsikan berkorelasi positif dengan kinerja bank dapat diasumsikan bahwa nasabah milenial tidak secara langsung memberdayakan informasi akuntansi dalam menentukan pemilihan bank. Dalam hal ini asumsi tersebut memerlukan pengujian lebih lanjut atas dasar data empiris. 


\section{DAFTAR PUSTAKA}

Alvara Research Center. (2017), The Urban Middle-Class Millennials Indonesia

APJII (2018). Hasil Survei Penetrasi dan Perilaku Pengguna Internet Indonesia 2018.Retrieved from https://apjii.or.id/survei

Badan Pusat Statistik. (2018). Profil Generasi Milenial Indonesia, Jakarta : BPS.

Badan Pusat Statistik. (2018a). Statistik Indonesia 2018, Jakarta : Kementrian Pemberdayaan

Perempuan dan Perlindungan Anak.

Barth, M. E., Landsman, W. R., \& Lang, M. H. (2008). International Accounting Standards and Accounting Quality. Journal of Accounting Research, 46(3), 467-498. doi: $10.1111 / j .1475-$ $679 x .2008 .00287 . x$

Chigamba, Cleopas. (2011). Factors Influencing the Choice of Commercial Banks by University Students in South Africa. International Journal of Business and Management, Vol. 6, No. 6; June 2011, pp.66-76.

Deloitte (2018), 2018 Deloitte Millennial Survey.

Fathelrahman, M. I. H. (2019). Determinant factors of consumers' bank selection decision in Suda. African Journal of Business Management, 13(15), 490497.
Howe, Neil, and William Strauss. (2000). Millennials Rising: The Next Great Generation /by Neil Howe and Bill Strauss ; Cartoons by R.J. Matson. New York: Vintage Books, 2000.

Lara, J. M. G., Osma, B. G., Mora, A., \& Scapin, M. P. (2017). Gender Discrimination and the Monitoring Role of Female Directors Over Accounting Quality. SSRN Electronic Journal. doi: 10.2139/ssrn.2732588

Lo, A. W., Wong, R. M., \& Firth, M. (2010). Can corporate governance deter management from manipulating earnings? Evidence from related-party sales transactions in China. Journal of Corporate Finance, 16(2), 225-235. doi: 10.1016/j.jcorpfin.2009.11.002

Mathova, A., Perdana, H. D., \& Rahmawati, I. P. (2017). Pengaruh Kepemilikan Keluarga dan Good Corporate Governance Terhadap Kualitas Laba dan Kinerja 76 Perusahaan. SAR (Soedirman Accounting Review) : Journal of Accounting and Business, 2(1), $73 . \quad$ doi: 10.20884/1.sar.2017.2.1.405

Otoritas Jasa Keuangan. (2019). Statistik Perbankan Indonesia Juli 2019. Retrieved from https://www.ojk.go.id/id/kanal/p erbankan/data-danstatistik/statistik-perbankanindonesia/Default.aspx 
Otoritas Jasa Keuangan. (2019a). Kegiatan Usaha Bank Umum. Retrieved from https://www.ojk.go.id/id/kanal/p erbankan/Pages/Bank-

Umum.aspx

Ozcelik, G. (2015). Engagement and retention of the millennial generation in the workspace through internal branding. International Journal of Business and Management, 10(3), 99-107.

Hinson, R. A. Osarenkhoe and A. Okoe, (2013). Determinants of Bank Selection: A Study of Undergraduate Students in the University of Ghana. Journal of Service Science and Management, Vol. 6 No. 3, 2013, pp. 197-205.

Saleh ,M.S.M., Rosman M.R.M., Nani N.K. (2013). Banks Selection Criteria in a Customers' perspective. IOSR Journal of Business and Management, 7(6), 15-20.
Sebastian, Yoris, Dilla Amran dan Youth Lab. 2016. Generasi Langgas: Millennials Indonesia, Jakarta : Gagas Media.

Situs Kominfo, (2016). https://www.kominfo.go.id/conte nt/detail/8566/mengenalgenerasimillennial/0/sorotan_media, $(27$ Desember 2016)

Twenge, J.M. ( 2010). A review of the empirical evidence of generational differences in work attitudes. Journal of Business Psychology, 25, 201-210

Utomo, W. P. (2019). Indonesia Millennial Report. IDN Research Institute, 01

Yunietha, \& Palupi, A., (2017) Pengaruh Corporate Governance dan Faktor Lainnya terhadap Manajemen Laba Perusahaan Publik Non Keuangan. Jurnal Bisnis \& Akuntansi. 19(1A). 292-303. 